\title{
Nutraceuticals and Nutraceutical Supplementation Criteria in Cancer: A Literature Survey
}

\author{
Rakesh Sharma*," \\ Department of Engineering and Technology, Tallahassee Community College, Tallahassee, Florida 32304, USA
}

\begin{abstract}
Nutraceuticals are natural and bioactive products with food value to keep energy balance in the body and promise substantial therapeutic value in several diseases. Major nutraceuticals are now part of nutrition supplements at nonprescription counters and their self-prescription is increased at large scale. The current literature suggests the nutraceutical use in most of cancer prevention and management. The biochemical mechanism of nutraceuticals is poorly reported and most of the literature indicates the success of nutaceuticals in experimental animals. Broadly nutraceuticals are antioxidants, omega-3 fatty acids, vitamins, minerals and dietary fibers. Most of the nutraceuticals are derived from plants and animal origin and act as biochemical metabolites either by direct intermediary metabolism or regulating immunity.
\end{abstract}

Key Words: Cancer, immunity, nutraceuticals, metabolites, diet, cancer prevention, nutraceutical supplementation.

\section{INTRODUCTION}

Nutraceutical was first defined in 1989 by Stephen De Felico "as foods, food ingredients or dietary supplements that demonstrate specific health or medical benefits including the prevention and treatment of disease beyond basic nutritional functions". Later nutraceuticals emerged as potential cancer preventive natural sources from food [1].

\section{Time Series of Nutraceuticals in Cancer Management}

The concept of nutraceuticals was initially considered as natural foods to provide energy as recommended daily requirement in the body for health till year 1990. Later the importance of nutraceuticals was realized as beneficial in different nutritional disorders with growing use of the nutraceuticals as self prescription in cardiovascular, cancer, developmental conditions in the last decade. In new era of $21^{\text {st }}$ century showed enormous growing awareness of nutraceuticals as potent therapeutic supplements with accepted concept of nutraceutical medicine as new branch of 'complementary and alternative medicine'(CAM). In last nine years, national and federal bodies accepted nutraceuticals as possible neutraceutical therapy in main stream of medical education and health. The healthcare industry demonstrated the shift of growing population from medical treatment of cancer towards non-prescription nutraceuticals as selfmedication in cancer management and prevention. The growing awareness of nutraceutical benefits and shift of

\footnotetext{
*Address correspondence to this author at the Department of Engineering and Technology, Tallahassee Community College, Tallahassee, Florida 32304, USA; Tel: (850) 410-6431; Fax: (850) 410-6150; Mobile: (850) 2648659; E-mail: rs05h@fsu.edu

"The manuscript is also part of internship in biotechnology and engineering under supervision of Dr. Zoreh Moshir at Tallahassee Community College, Tallahassee and Dr. Ching J. Chen at FAMU-FSU College of Engineering, Florida State University, Tallahassee, Florida 32310 . Author is affiliate scientist at Columbia University, USA. Present address: 2525, Pottsdamer Street, Florida State University, Tallahassee, Florida 32310 , USA.
}

healthcare economics in favor of nutraceuticals brought neutraceutical medicine in spotlight of government health policy on systematic use of nutraceuticals in prevention and control of various chronic diseases. In last six years, National Cancer Institute (NCI) and other global efforts have documented fact sheets and several health documents on nutraceuticals in cancer management as shown in Fig. (1). The major efforts were devoted in investigation of inhibitory effect of active nutraceutical component(s) on cell proliferation, cancer oncogenesis to result the reduced metastasis, delayed apoptosis, reduced necrosis and rate of malignancy growth in initial stages. In last two years the use of nutraceuticals in prevention and disease control has been extended further as protective nutrition supplementation policy of center of disease control (CDC) under its independent supervision. However, mechanisms still remain unproven and unvalidated but practice of nutraceuticals as food supplements in cancer prevention is acceptable.

\section{WHAT ARE NUTRACEUTICALS?}

Nutraceuticals are natural bioactive chemical compounds. Nutraceuticals have value in health promoting, disease preventing or semi-medicinal properties. Nutraceuticals are found as natural products from (a) the food industry, (b) the herbal and dietary supplement, (c) pharmaceutical industry, and (d) the newly emerged bioengineered microorganisms, agroproducts or active biomolecules. It may range from isolated nutrients, herbal products, dietary supplements and diets to genetically engineered "custom" foods and processed products such as cereals, soups and beverages [2]. Chemically the nutraceuticals may be classified as isoprenoid derivatives (terpenoids, carotenoids, saponins, tocotrienols, tocopherols, terpenes), phenolic compounds (couramines, tannins, ligrins, anthrocynins, isoflavones, flavonones, flavanoids), carbohydrate derivatives (ascorbic acid, oligosaccharides, non-starch polysaccharides), fatty acid and structural lipids (n-3 PUFA, CLA, MUFA, sphingolipids, lecithins), amino acid derivatives (amino 
acids, allyl-S compounds, capsaicnoids, isothiocyanates, indols, folate, choline), microbes (probiotics, prebiotics) and minerals ( $\mathrm{Ca}, \mathrm{Zn}, \mathrm{Cu}, \mathrm{K}, \mathrm{Se})[3]$.

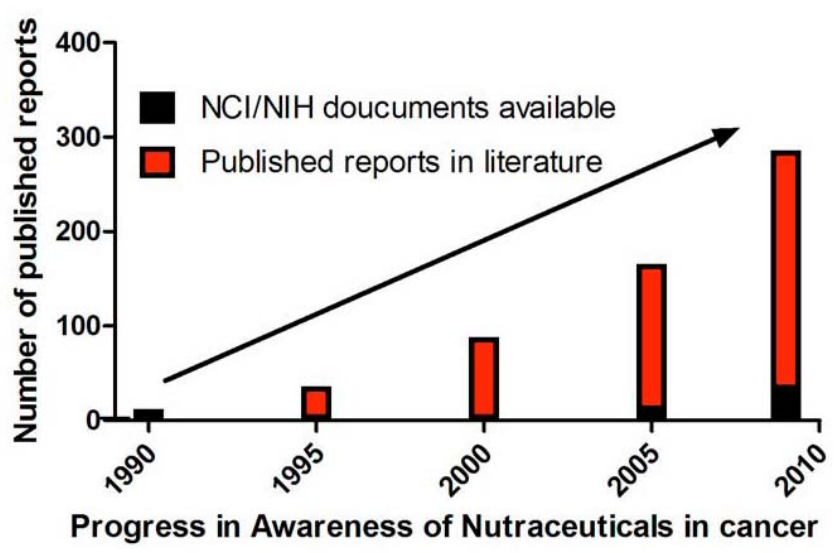

Fig. (1). The figure represents the time line of nutraceuticals in cancer prevention and growing awareness as documented in literature available in last 15 years.

Broadly the nutraceuticals were reported as active natural compounds as compiled in Table 1. Recently, Tripathi et al. 2005 reported the chemotherapeutic value to nutraceuticals in cancer. Majority of cancer prevention evidence comes from animals studies on phytochemicals, fat, flavones, phytoesterogens, isoflavonones, genestein, curcumin, capsaicin, epigallocatechin-3-gallate, gingerol, lycopene, antaoxidants, vitamins, minerals [3, 4]. Self-described testimonies of nutraceutical medicine and its success accrued over years in favor of liquorice(for peptic ulcer), isoflavones (for cholecarotenoids, saponins, tocotristerol lowering, osteoporosis), phosphatidylcholine(for hepatitis), ginger(for emetic disorder, dizziness, carminative), kambocha tea (for arthritis), glucosamine(for chondroitin), vitamins $\mathrm{C}, \mathrm{D}, \mathrm{E}$, minerals $\mathrm{Zn}$, $\mathrm{Se}, \mathrm{Cu}$ (for lycopene, lutein(for antipain), leupeptin, urokinase inhibitor (for prostate cancer), fenugreek osteoarthritis), lycopene, glucans(for cardiovascular disease), green tea(for cancer), carotenoids, Trigonella foenum-graceum (as antidiabetic, anti-cancer), noni Morinda citrifolia (for relief blood pressure, muscle pain), Thymus vulgaris, rhus coriaria (for antibacterial activity), sorrel (for immune system), Geranum sanuineum (as antiviral) over years [3, 5]. Lycopene, silbinin, shark cartilage, vitamin D (to decrease osteoporosis and bone pain), green tea, Selenium and vitamin E, Grape seed extract, modified citrus, pectin, Soy, PC-SPES are cited as prostate cancer protective food supplements [5].

\section{Dilemma of Nutraceuticals}

Nutraceuticals may act as essential nutrient, as drug like, as regulatory biochemical metabolite and as phytohormone in the body. Recently, some prominent evidences are reported in favor of cancer inhibitory metabolic activity of nutraceuticals in the human body:

1. Nutraceuticals may act as essential amino acid drug like essential nutrients. For example, tryptophan is needed for protein synthesis at low dose in humans. At high dose, it increases brain 5-hydroxytryptamine levels and thus acts as a drug to treat the insomnia [6].
2. The nutraceutical preparations containing phytosterols are effective in lowering LDL cholesterol and osteoporosis.

3. Bovine milk fat globule acts as anticancer, anticholesterolemic, coronary heart disease [7].

4. The phytonutrients prevent cell proliferation and play significant role in the prevention of chronic degenerative diseases. Notable examples are ginseng, spirulina, gingko biloba, amino acids, glucosamine, chondroitin and Aegle marmelos. Herbal and medicinal plants have shown significant inhibition of cell proliferation [8]. Phytoesterogens play role in reducing necrosis.

5. Vitamin C, vitamin E, $\beta$-Carotene, lycopene (carotenoids), lipoic Acid, glutathione(thiols) play role in cancer prevention and inhibition of necrosis; Co-Enzyme Q-10, super oxide dismutase (enzyme), selenium, copper, manganese, zinc (minerals) act as anticancer nutraceuticals in cancer management by delayed apoptosis observed in isolated cancer cells [9].

6. Oligosaccharides were tested in animals. Fructo-oligosaccharides, Inulins, Lactilol, Lactulose, Galacto-oligosaccharides, Soybean oligosaccharides, Lactosucrose, Isomalto-oligosaccharides, Gluco-oligosaccharides, Xylooligosaccharides showed reducing cancer cell divisions [10].

7. Polyunsaturated fatty acids (PUFA) such as safflower oil, corn oil, soybean oil, mustard oil, evening primrose oil, flax oil, hemp seeds, borage seeds showed protective effects in heart disease and stroke, rheumatoid arthritis, inflammatory arthritis, inflammatory bowel disease, asthma, cancer, chronic lung failure, kidney transplant, and bone formation [11].

8. Dietary fibers such as oats, dried beans, legumes, chicory as water soluble fibers, apple, orange, apricot, plum, pine apple contain $18-30 \%$ fiber contents. The vegetable sources such as cabbage, carrot, lettuce, onion, tomato containing 9 to $12 \%$ fiber contents showed antioxidant and cell proliferation inhibitory properties [12].

9. Wild foods are other major source of nutraceuticals and phytoesterogens. Most of the wild plants, wild mushrooms, wild fungi, wild vegetables, wild nuts, wild fruits and wild flowers as whole are considered as potential natural therapy alternatives $[8,13]$.

10. Soy isoflavones, genistein, curcumin, capsaicin, epigallocatechin-3-gallate (EGCG). gingerol, lycopene have emerged as established cancer protective nutraceuticals [14].

\section{ANIMAL STUDIES}

A large volume of literature is available on nutraceutical inhibitory effect on cancer cell growth based on observations of cultured cancer cell proliferation, enhanced apoptosis, antioxidant action etc. Still attempts are in the direction of morphological, cytomorphic, histopathology evidences of nutraceutical induced tumor shrinkage, arrested cell growth, delayed premalignancy, delayed oncogenesis, cell DNA cycle inhibition by using 3D localized molecular imaging techniques. Previous studies on micro-MRI and 
Table 1. The Examples of Nutraceuticals are Shown with Their Benefits in Different Cancers and Mechanism of Chemoprotective Action in the Body. The Structure of Active Nutraceuticals are Shown with Mechanism and Their Structure with Formula in Chemical Nomenclature

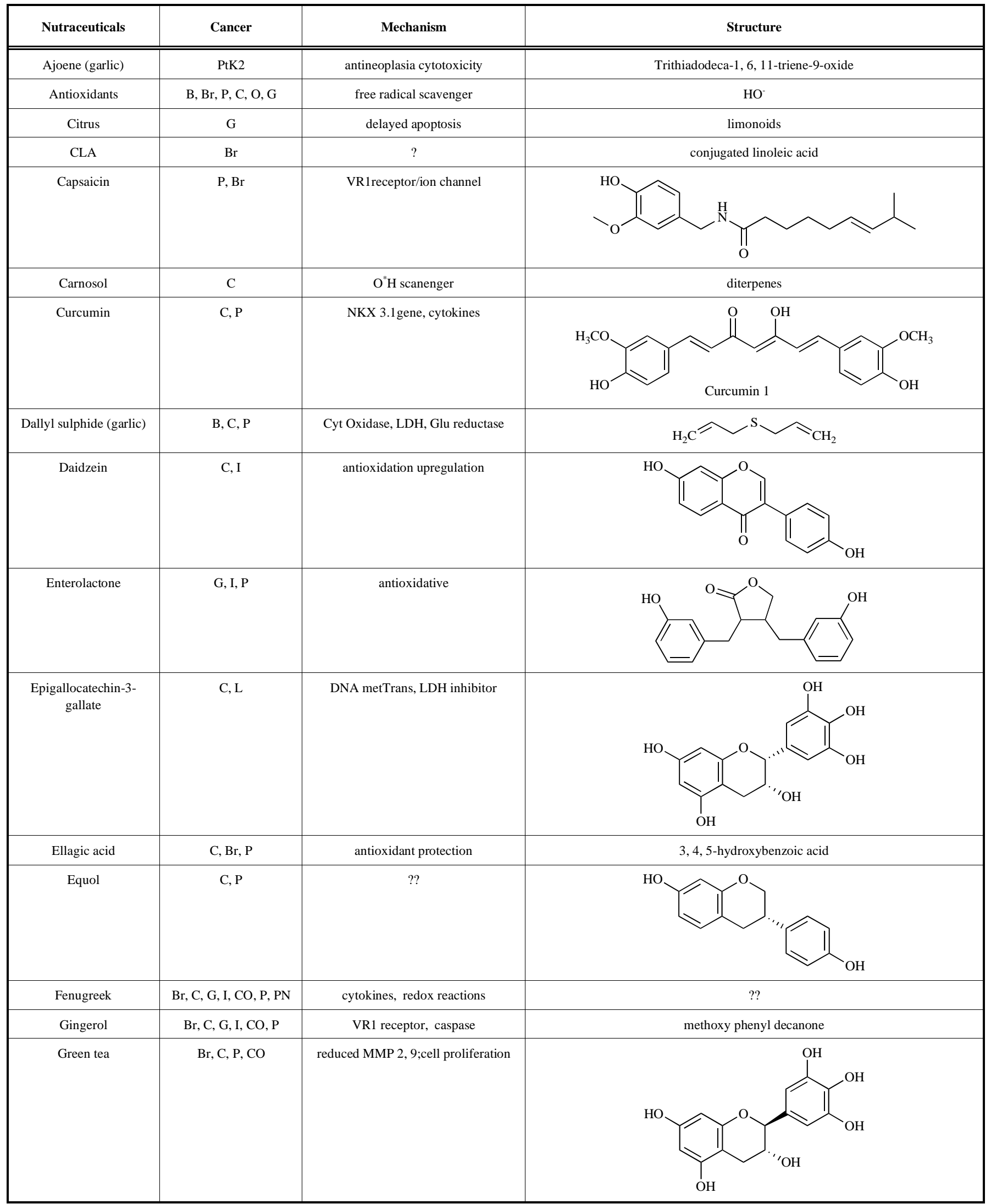


Table 1. Contd....

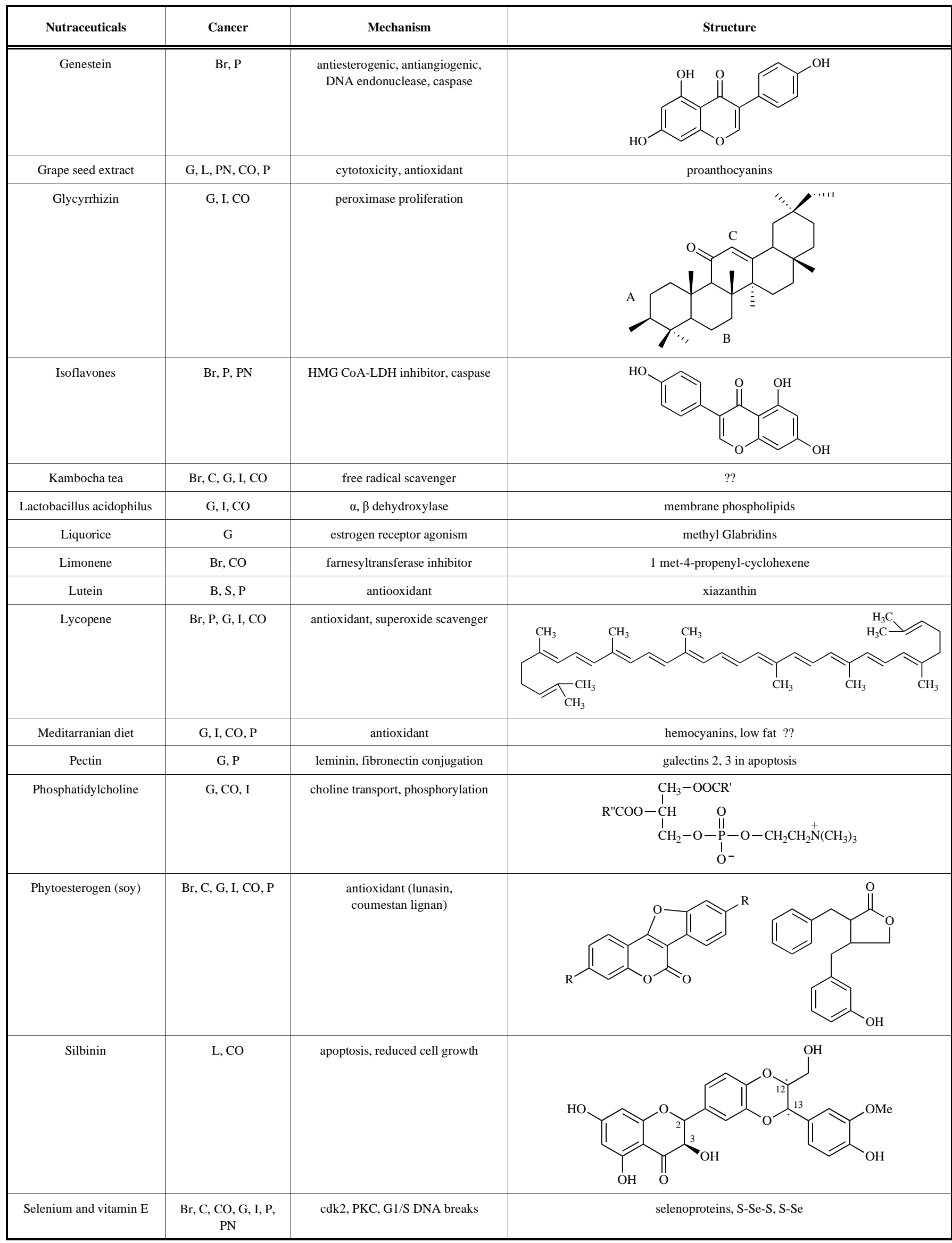


Table 1. Contd....

\begin{tabular}{|c|c|c|c|}
\hline Nutraceuticals & Cancer & Mechanism & Structure \\
\hline Sphingolipid & $\mathrm{Br}, \mathrm{P}, \mathrm{G}, \mathrm{I}$ & $\begin{array}{l}\text { cell cycle arrest, apoptosis, senescence } \\
\text { and differentiation }\end{array}$ & \\
\hline Soy, PC-SPES & $\begin{array}{c}\mathrm{Br}, \mathrm{C}, \mathrm{CO}, \mathrm{G}, \mathrm{I}, \mathrm{P}, \\
\mathrm{PN}, \mathrm{O}\end{array}$ & $\mathrm{G}_{2} \mathrm{M}$ cell cycle kinase, cytokines & chalcones \\
\hline & & cyclooxygenase inhibition, apoptosis & $\gamma$ tocopherol \\
\hline Vitamins and minerals: & all cancers & oxidative phosphorylation & active vitamin forms \\
\hline A & & proton pumps & retinal \\
\hline B & & phosphorylation, redox reactions & pyrophosphates \\
\hline Copper & & catalase inhibitor, angiogenesis & ceruloplasmin \\
\hline Potassium & & $\mathrm{Na} / \mathrm{K}$ channels & $\mathrm{K}+$ or bound protein \\
\hline Zinc & & Zn-endopeptidases(MMP) inhibition & cofactor in enzymes \\
\hline
\end{tabular}

A: Arthritis cancer; B:Bone cancer; Br:Breast cancer; C:Common malignant cancers; CO: Colon cancer; H:Liver cancer; G: Gastric cancer; I:Intestinal cancer;L: Leukemia; P:Prostate cancer; PN: Pancreatic cancer; O:Ovarian cancer(source: Mazzio E Souleman K. US Patent 20070248693 http://www.freepatentsonline.com/y2007/0248693.html).

immunostaining suggested the reduced apoptosis in experimental rat MCF-7 explanted breast and mice PC-3 explanted prostate animal tumors. The increased sodium and enhanced apoptosis of tumor cells showed the tumor shrinkage after anticancer intervention to animals after 24 hours as shown in Fig. (2) [15]. Major evidence was the slowed down apoptosis rate (less nuclear beads), reduced proliferation, less cyst size, less necrosis, single strand DNA breaks and poor carcinoma and neoplasia growth in treated groups [16]. The mechanism of these nutraceuticals still not established and it remains to investigate more scientifically diet controlled experimental methods. Moreover the beneficial effects of nutraceuticals in experimental animals were reviewed and two third literature reports on nutraceuticals are documented on experimental animal cancer studies as either reviews or animal bench experiments on cancer prevention. The clinical evidence of nutraceutical cancer prevention success is still based on biochemical mechanisms of nutrients in diets reported over several decades. Some mechanisms of nutraceutical action are reported as immune modulatory, induced apoptosis, removal of free radicals, inhibited cell proliferation, inhibited necrosis. New ayurved (Indian traditional medicine) concepts are also emerging as powerful nutraceuticals in cancer prevention. The growing literature on mechanism of nutraceutical action in the cancer is supporting the extended benefits of nutraceuticals but it further needs more investigations as described in following separate section of new literature evidences.

\section{BIOCHEMICAL BASIS OF NUTRACEUTICALS IN CANCER PREVENTION}

Natural vegetables, herbs, plants, wild foods are complex in structural composition. The biochemical basis of individual source of these foods is not explored due to their complex nature. Some of the evidences are in favor of the active food principles as nutraceuticals to show anticancer or preventive cancer supplements. Some of nutraceuticals are in the phase of clinical trial or already available as food supplement. Complementary and Alternative Medicine is emerging in prevention of chronic premalignancies as safe practice because of the high risk of mortality and long-term morbidity associated with surgical procedures of cancer management and high side effects of chemotherapy. Herbal medicines have shown reduced cell proliferation in cultured cells. The vitamins, minerals, dietary fat play a role in relation to cancer prevention and control. The mechanisms of nutraceutical action can be discussed broadly in following categories based on active metabolites present in nutraceuticals.

1. The glutathione is the liver's most abundant protective constituent of antioxidant glutathione reductase enzyme. Glutathione functions as a substrate for the two key detoxification processes in the liver: 1. transforming toxins into water soluble forms, 2. neutralizing and "conjugating" with toxins for elimination through the gut or the kidneys. If either of these processes is impaired for any reason, toxins will accumulate in the body and lead to disease.The best nutrition with liver cancer focuses on improving the body's glutathione reserves [4].

2. Some nutraceuticals rich in opiads are tumor inhibiting and these nutraceuticals showed the activity to get rid of toxins such as heavy metals, chemicals, digestive by products, etc. Tobacco plants may also help person to fight against lymphoma [17].

3. The Soy isoflavone Haelan951 (genistein and genistin) was reported to have some role as a chemopreventive agent against cancer in humans [18]. Beta-glycoside 


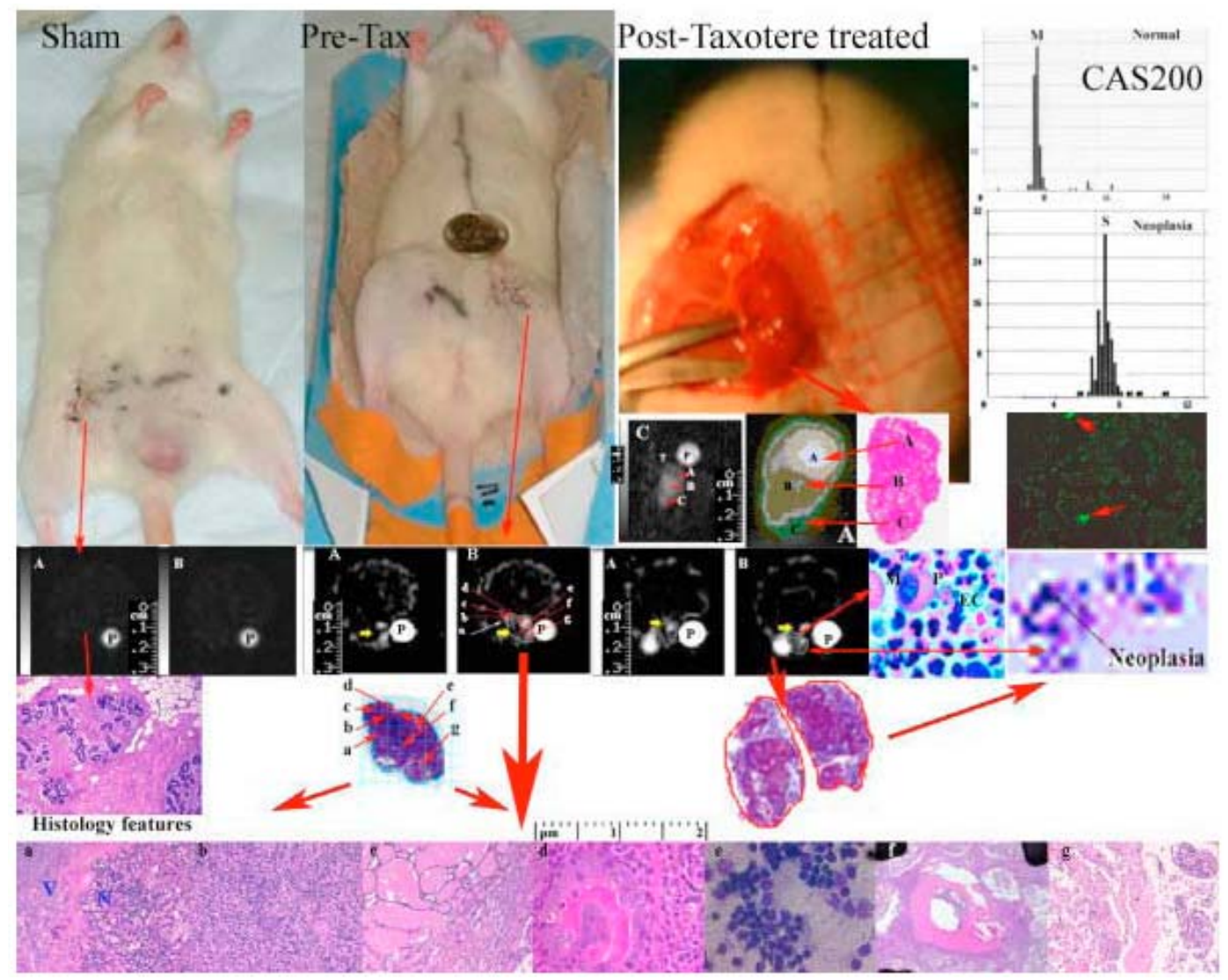

Fig. (2). The sham control, pre-treatment and Taxotere post-treated animals (top panels on left) show tumors as SQ sodium (A) and IR sodium (B) images at $0 \mathrm{hr}$ pre-Taxotere and 24 hours post-Taxotere treatment (panels $\mathbf{A}$ and $\mathbf{B}$ on second row). On third row on left, control tumor histology shows normal vesicles. Pre- and post treated excised tumor histology by trichrome staining is shown with delineated area. On fourth row on left, the excised tumor histology features in high power fields are shown with arrows (active viable cells (a), proliferation (b), necrosis (c), apoptosis (d), mitosis (e), fibrous cyst (f), and infiltrating ductile carcinonoma (g) in different x- and y-coordinate locations after coregistration with IR sodium images. On right, panels on top show a IR sodium MR image before (C) and after non-parametric segmentation by Optimas 6.5 to highlight the different signal intensities that appeared hyperintense, isointense, and gray-green colored on segmented image and histology features showed them as apoptosis (A), necrosis $(\mathbf{B})$ and neoplasia $(\mathbf{C})$. On right, second row shows corresponding S DNA histograms of neoplasia features by CAS 200 (panels on top), apoptosis staining (panel with green stain). On right, third row shows a post-Taxotere treated tumor histology by pentachrome stain to highlight mitotic figures (M) with active PMN cells (P) and high EC volume (EC) and corresponding digitized map of DNA cycle, with neoplasia shown as arrow. Reproduced from reference [15].

conjugate, genistin is abundant in fermented soybeans, soybean products such as soymilk and tofu. The betaglycosyl bond of genistin is cleaved to produce genistein by microbes during fermentation to yield miso and natto. Soy sauce has high isoflavone but low miso and natto contents. How much soy isoflavones needed? 1.5-4.1 $\mathrm{mg} /$ person miso isoflavone and $6.3-8.3 \mathrm{mg} /$ person natto respectively $[18,19]$.

4. Green tea has always been considered by the Chinese and Japanese peoples as a potent medicine for the maintenance of health, endowed with the power to prolong life [19]. Recently, Yean Lee et al. looked at the effects of the main active green tea constituent, epigallocatechin-3gallate (EGCG) on chronic lymphocytic leukaemia B cells isolated from leukaemic patients. These cells were characterised by their resistance to apoptosis because they secrete and bind vascular endothelial growth factor $[14,20]$.

5. Some herbal plants act as medicine. The herbal extracts are known to reduce the cell proliferation.

\section{APOPTOSIS AND IMMUNOLOGICAL LOSS AS BA-} SIS OF CANCER AND ROLE OF NUTRACEUTICALS

Cell mediate immunity is active and strong in youth and deteriorates with age. The major cytokines including inetrleukines, TNF alpha and NFKappaB loose their synergy response and affect cell mediated immunity to synthesize enough IgG, IgM, IgD antibody molecules. Humoral immunity also gets affected by less helper and suppressor lymphocytes. The possible metabolic points likely changed by nutraceuticals in apoptosis cascade and immunity loss are shown in Fig. (3).

\section{ALTERNATIVE APPROACHES OF NUTRACEUTI- CALS IN CANCER}

Children below 18 years probably do not need nutraceuticals. Adults over 20-40 years need nutraceuticals and monitoring cancer. Persons over sixty years in age, need cancer watch and nutraceuticals as mendatory daily dietary supplements in practice. These senior persons may show the following major symptoms as causes of cancer development [21]. 


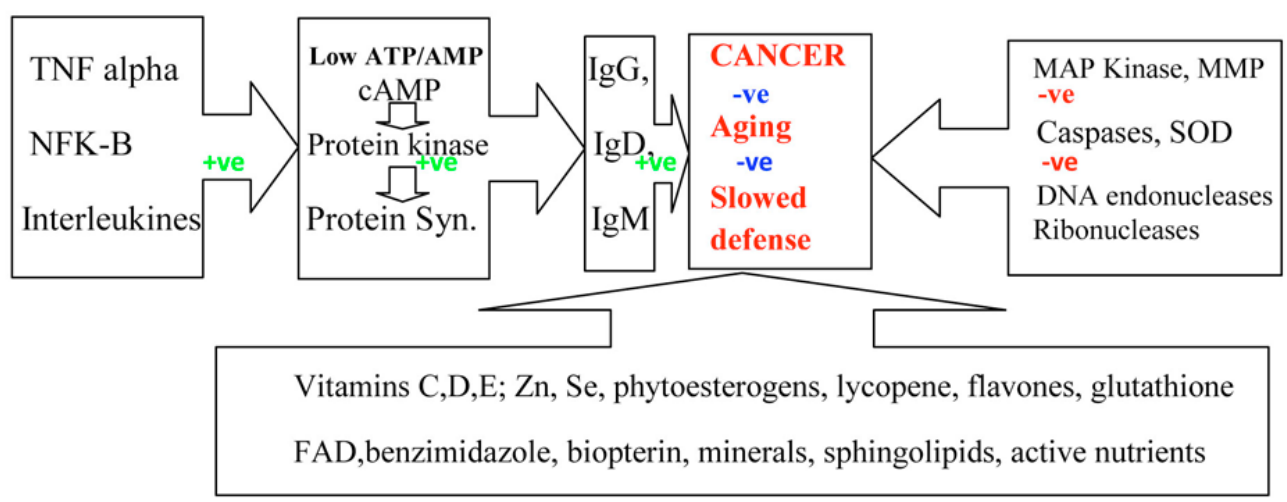

Fig. (3). The figure represents the model sketch of cascade of steps to show delayed and slowed down apoptosis and immunity recovery by nutraceuticals based on literature data. Note the possible points where nutraceuticals may likely regulate or control for further metabolism in cell and tissues. +ve sign represents stimulated and -ve sign represents inhibited action of nutrceuticals based on reported literature. (source: http://www.freepatentsonline.com/y2007/0248693.html).

- Abrupt and sudden weight loss, infection, overgrowth of localized tumor

- Poor cytokines, inflammatory proteins gradually lead to apoptosis, loss of immnunity

- Arteries and veins (and other tissues) become less elastic, as evidenced by our skin. Blood pressure may rise, as arteries lose their elasticity. (The amino acid taurine, found in fish, softens arteries and veins, as well as other connective tissue).

- Inflammation and cholesterol-filled growths (plaques) in our blood vessels reduce their rates of flow. The loss of elasticity causes the heart to pump with less power and force.

- Joints become inflammed, as the immune system ages and disease condition attacks the collagen of the joints.

- Insulin levels begin to rise as old cells become less responsive to insulin, and the pancreas increases its output to compensate. This eventually leads to Type II diabetes and pancreatic cancer in which old cells no longer respond to insulin and end up with heavy cardiovascular damage and cancer.

- Kidneys lose reserve capacity, gradually fail to do normal function and develop renal cancer.

- Reduced cell mediated immunity and humoral immunity leads to immune deficiency and cancer.

\section{PRESENT STATE OF ART ON NUTRACEUTICAL MEDICINE IN CANCER PREVENTION}

The UNISCI article, "Diet Called Most Important Breast Cancer Risk Factor", discusses the relationship between breast cancer and vitamin $\mathrm{D}$, and between breast cancer and animal- versus plant-derived foods [22]. Bottom line: diet and environment exposure are two major risks. Major question is if nutraceuticals can reduce the chance of getting cancer through dietary modifications? Answer is not clear. The statement of National Cancer Institute's recommendations is "to eat at least 5 servings of brightly colored fruits and vegetables a day, to restrict ingestion of animal products (excluding farm-bred fish) while upping vegetable sources of protein (e. g., beans), to consume cooked tomato sauces, and to insure that we get, perhaps, $200 \mathrm{mcg}$. a day of selenium. (found in Walmart's OneSource multivitamin capsule)"[23]. FDA requires appropriate scientific evidence regarding safety of nutraceutical use as daily prescription. However, new recommendations suggested that daily diet must contain 6.25 grams of soy protein per serving, micro-compound allicin (a small component of garlic) ad libitum amount, ecosapentanoic acid/docosaheaxanoic acid as polyunsaturated fatty acids (PUFAs) from fish or fish oils. The complementary medicine and alternative medicine approach is emerging as regulated tool to prescribe the norms of nutraceuticals as daily supplements in cancer and other diseases [24]. Fish and fish oils are compiled in Table 2.

\section{Insurance and Prescription}

National and federal agencies such as NCI and FDA need evidences and established data in large trials to approve nutraceuticals in clinical practice. In lack of such evidences and database, still nutraceutical practice remains at the door steps as nonprescription self-prescription available on counter. As a result, insurance companies still shy to accept nutraceuticals as prescription.

\section{Criteria of Suggested Practice of Nutraceuticals in Cancer Prevention}

The use of complementary and alternative medicine (CAM) is increasing rapidly in developed countries [24].

Functional Foods \& Nutraceuticals in Cancer Prevention were highlighted as tomato, dietary fibers, soy, phystoesterogens, herbs, cruciferous vegetables [25].

NTP-2000 and NIH-07 diets were reported rich in nutraceuticals to meet recommended daily allowances. NTP2000 diet has lower protein, higher fiber, and higher fat than the NIH-07 diet. Both diets were suggested as preventive in cancer. Main causative factors of cancer were free radicals, vitamin C, D, E deficiency, Se deficiency, loss of cellular immunity in daily diet [26].

Recently, National Cancer Institute put forth the efforts on alternative ways of cancer prevention as public awareness to main focus on life style, prevention and control care measures, eating habits, hazardous contaminents with several successful attempts of antioxidants, garlic, vitamins [27]. 
Table 2. The Table Represents the FDA Approved Major Nutraceuticals with Recommended Quantity and Sources of Nutraceuticals on Shelf in Super Markets

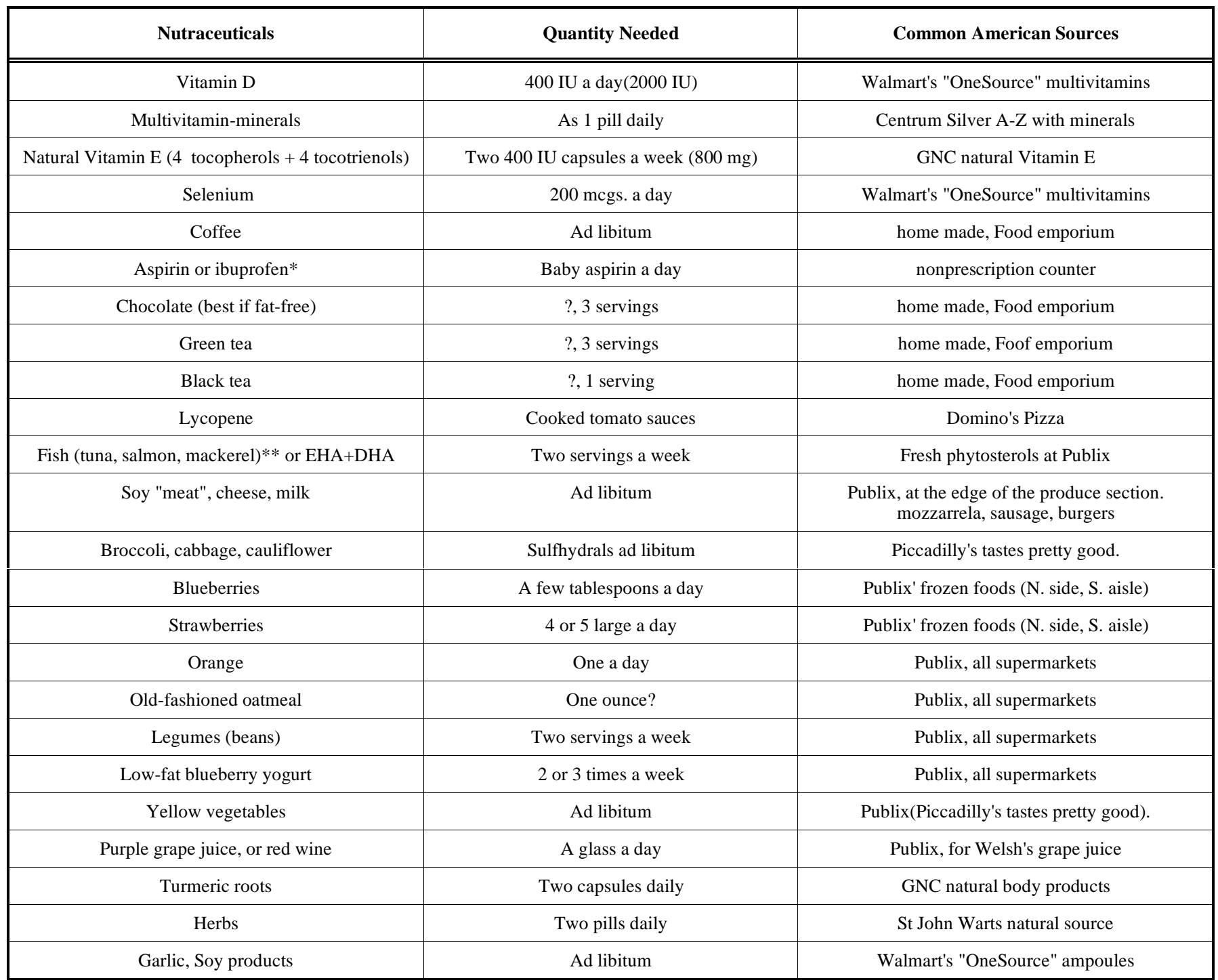

*aspirin and ibuprofen primarily act as anti inflammation. (Other agents such as fish also have anti-inflammatory properties.); **Tuna and mackerel contain mercury, dioxin, and PCB's. The salmon fish is safe. Winn Dixie farm-raised salmon. canned salmon provides omega-3 fatty acids and , taurine which are vital to the nervous and cardiovascular systems (modified from the Source [27-30]).

\section{NEW LITERATURE BASED EVIDENCES OF NUTRACEUTICALS IN CANCER: YEARS 2002-2008}

In recent years during 2002-2008, the major focus was on more evidence based wider use of multivitamin-multimineral combined with isolated bioactive components from plants and functional foods in various cancer types. In last 4 years maximum efforts were devoted on reviews and compilation of evidenced experimental results on nutraceuticals in reducing cancer progress and identification of associations of active food components in diet with reduced cell proliferation, necrosis and apoptosis. However, NCI views that sequential events during the nutraceutical treated cell growth or arrest cancer are controversial [31]. The literature during years 2003-2008 suggested major information for following: 1. direct link of vitamins, minerals in cancer prevention; 2 . new bioactive food components with new mechanism of arresting cell growth; 3. more controlled trials and regulated studies under federal support; 4. new awareness of unpopular foods in cancer prevention; 5. new federal and statuary guidelines on nutraceutical recommended allowances and marketing.

The following information is grouped based on literature on nutraceuticals and nutraceuticals in cancer management with major focus on controlled randomized trials in experimental cancers and clinical cancer subjects. The description is divided into three sections.

\section{Nutraceuticals in Cancer Prevention During Years 2002-2008}

The major nutraceuticals were reviewed and reported as vitamins and minerals, phytochemicals. The vitamins $\mathrm{A}, \mathrm{B}_{6}$, $\mathrm{B}_{12}, \mathrm{D}, \mathrm{E}$, folate have been reported as anti cancer, immunoprotective and reducing cancer risk in population at risk of cancer and individuals who used self-medication [32-40]. These reports provided the information of growing self- 
prescription style among population without any harmful effect and growing confidence of cancer bearing and avoiding chemotherapy. These nutraceutical supplements were reported in controlled epidemiological surveys to reduce morbidity and cancer incidence in clinical studies [41-47]. New information was investigated on successful nutraceutical supplements in present day life style, affluence and daily nutraceutical rich diet with reduced cancer prevalence in these studies. Major minerals as magnesium [48], zinc, micronutrients [49-52], selenium [53-57], calcium and were scientifically explored for their efficacy and safety in cancer prevention. Other new concepts emerged on the role of dietary vitamins as anitioxidants in primary and secondary cancers in meta-analysis, randomized trials and epidemiological evidences with established metabolic and biochemical mechanism of these nutraceuticals [58-66]. The fatty acids [67, 68], polyphenols and phytochemicals emerged recently as promising chemopreventive agents to reduce cell proliferation and necrosis, enhanced apoptosis, reduced free radicals [69-75]. Soy phytoesterogens and isoflavones emerged as single potent chemopreventive agents to reduce the cancer risk [76-78]. Around the globe federal and government efforts have accumulated on consensus for statutory policy to use nutraceuticals on their daily requirements, supplementation, combinations and dosage to prevent or manage the cancer [79-83]. Randomized and double blind control trials indicated the increased importance of vitamins, herbs and fresh vegetables as likely protective supplements [84-90], tomato (lycopene) in prostate cancer prevention [91-93], nutritional intervention in different cancers of different body organs in the body [94-100]. New concept of Mediterranean diet was introduced to reduce the risk of cancer along with cardioprotection [101-104]. However, these reports are not conclusive and remain to establish the effectiveness of nutraceuticals if nutraceuticals effect on cancer cell senescence, oncogenesis, transformation, cell-cell contact inhibition, DNA fragmentation, ploidy and anisonucleosis without showing any adverse effect on normal cells.

For interested readers, a tentative sketch is outlined to understand the possible biochemical mechanistic and regulatory pathways and the role of nutrceuticals in cancer cell metabolism shown in Fig. (4).

\section{Mechanism of Cancer Prevention by Nutraceuticals}

Several approaches have been reported to investigate the role of nutraceuticals on reduced cell damage in the normal cells of the body and possibility of delayed apoptosis, DNA interaction, reduced necrosis, cell proliferation, signaling and maintaining metabolic integrity in the cancer tissue as cancer prevention mechanisms [105-108]. The biomarker of cancer such as metalloproteinases [109], vitamin D hydroxylase [110], interleukins [111], omega-3 fatty acids [112], induced neutropenia [113], DNA adducts [114], DNA methylases [115], polymorphism [116], superoxide dismutase [117] have been discovered as potent indicators of nutraceutical chemopreventive mechanism. Still the action of phytochemicals and role of bacteria is not understood [118, 119]. Recently mechanisms of nutraceuticals were reviewed thoroughly [120]. Sharma et al. 2008 established the mecha- nism of intracellular sodium as major player in breast and prostate tumors to induce delayed apoptosis [121]. The MRI and PET techniques evidenced the coexisting mechanism of reduced glycolysis and intracellular sodium release in tumors as chemoprotective assay [121].

\section{Cancers in the Human Body and Nutraceutical Protection}

The awareness of cancer prevention by nutraceuticals began in late of the last decade. Still federal agencies restricted the regulatory policies of nutraceutical use in cancer prevention. Complementary and alternative medicine began a new era of harmless non-prescribed drugs with rampant success of self-prescription and on-counter sale of nutraceuticals. In last five years evidenced wider acceptance of nutraceuticals by both public and federal agencies. The major health hazards were identified as breast, prostate, colorectal, ovarian, pancreatic, and skin cancers.

The breast cancer was identified as single major health hazard three decades ago and still it remains a major risk among women. Different nutraceuticals have been reported in reducing breast cancer risk at both self-medication at homes and health centers. The major impact of experimental animal studies was distinct observations of reduced cancer cell growth by nutraceutical intervention and it supported the role of nutraceuticals in cancer prevention and treatment. The major examples of breast cancer preventive nutraceuticals are soy genestein [122-124], isoflavones, multivitamins as scavengers of free radicals, antioxidant, mitochondrial oxidative phosphorylation [125-132].

The prostate cancer was still recognized as single major health hazard among males and remains as main focus of nutraceutical intervention to reduce cancer risk by randomized control clinical trials. The major examples of cancer protective nutraceuticals are multivitamin antioxidants [133, 134], soy isoflavones [135, 136], soy-tomato combo products [137-139]. Majority of experimental animal cancer studies supported the reduced prostate cancer by nutraceutical supplementation. Still it remains to establish the value of nutraceuticals in clinical prescription at health centers. In this direction, lot of academic and global federal efforts are going on to establish the long term benefits of nutraceuticals in prostate cancer risk [140-145]. The increased awareness and self-prescription of nutraceuticals among public for prostate cancer benefits is present major concern of health authorities [146-153].

Lung cancer and esophageal cancer remained as ignored health hazards perhaps due to other responsible environmental factors as main causative determinants of respiratory diseases with possible cancer risks. Recently few reports suggested the possible increased nutraceutical benefits of vitamins $\mathrm{A}$ and $\mathrm{E}$ in protection against lung cancer [154-157].

Colon and colorectal cancers have been identified as health hazards of modernization in food processing, artificial foods and affluent eating life style in metro cities and fast pace society [158]. The increased incidence of colon, colorectal cancers have shown the processed food diet as 


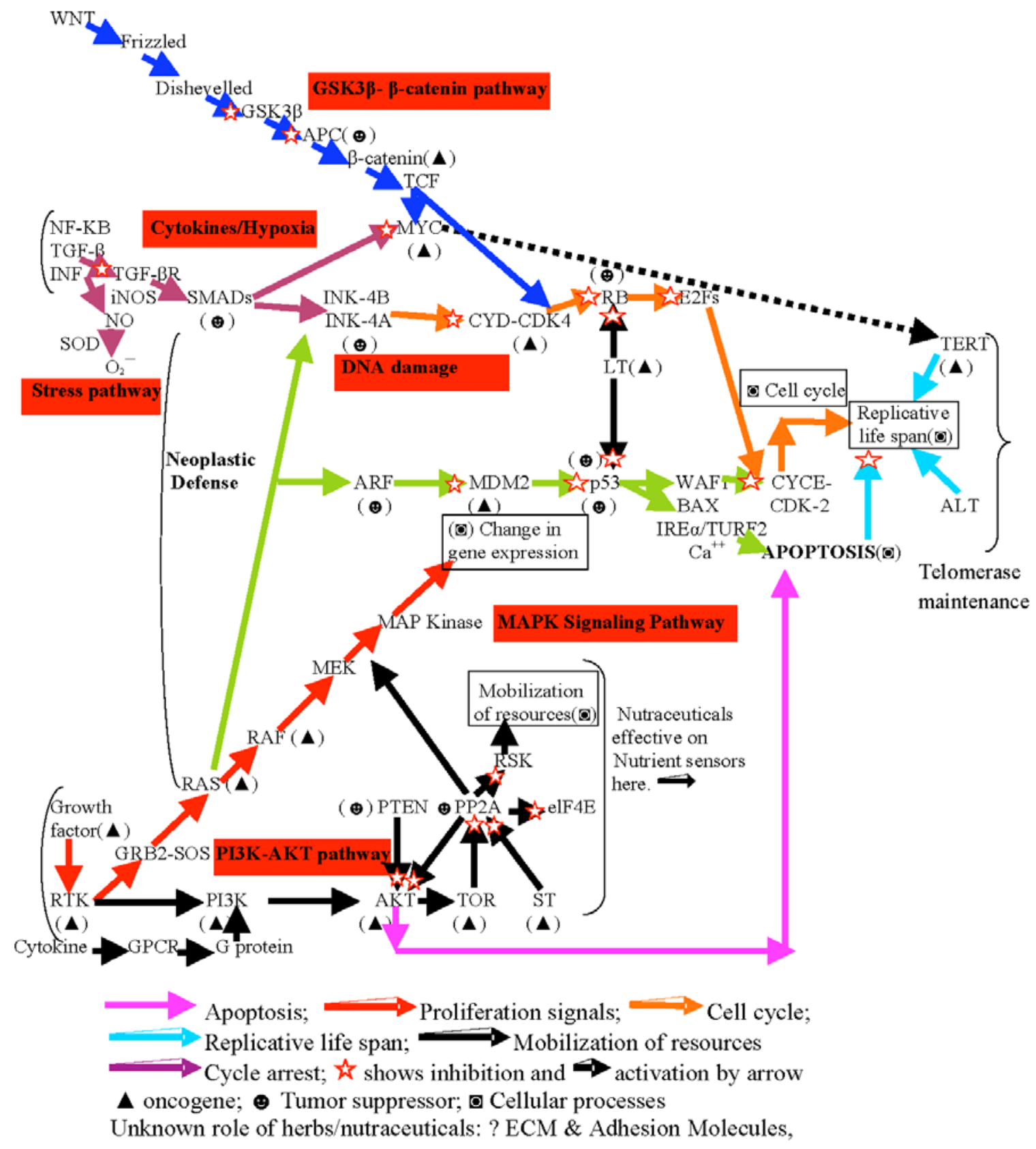

Fig. (4). An eye-view of nutraceutical action based on experiments in literature.

main source of cancer. The colorectal and colon cancer is widely reported as reduced by use of nutraceuticals such as folate [159-163], calcium [164-167], tomato-soy diet [168, 169], fiber [168-171] and vitamins [172].

However, there are hypes and controversies in risk assessment of nutraceutical in esophageal and gastrointestinal cancer management [173]. The several reports highlighted the trade-off between increased neoplasia in gastric cancer and the limits of nutraceuticals to reduce cancer growth [173, 174]. Still efforts are in the direction of antioxidant nutraceuticals to prevent or arrest the gastric cancer growth [175].

The ovarian and endometrial cancers are at increase among privileged woman population and increased awareness of vitamins and minerals have shown a new hope to reduce the risk of cancer. Vitamin A, D, antioxidants, calcium, folate nutraceuticals still remain a choice as cancer preventive supplements [176-178].

Still efforts are in progress to observe more and more growing use of nutraceuticals in less known cancers. Recently less reported and newly investigated cancer protection by nutraceuticals were evidenced for lymphoma [179], skin cancer [180], pancreatic cancer [181-183]. Recently vitamins and minerals were validated in chemoprevention trial of different cancers [184]. In other recent reports the investigators showed a positive response of different nutraceutical supplements and foods in cancer prevention of different organs in the body as shown in Table $\mathbf{3}$ with nutraceuticals and references. 
Table 3. The Table Represents the Documented or Approved use of Nutraceuticals in Prevention or Management of Cancer in Different Organs

\begin{tabular}{|c|c|c|}
\hline Cancer & Nutraceuticals & References \\
\hline \hline Bone cancer & soy isoflavones & {$[5]$} \\
\hline Breast cancer & lycopene, phytoesterogen & {$[122-132]$} \\
\hline Common cancer & cruciferous vegetables & {$[25,184]$} \\
\hline Colon cancer & nuts, fibers & {$[158-172]$} \\
\hline Gastric cancer & herbs & {$[173-175]$} \\
\hline Intestinal cancer & sphingolipids & {$[64,65,176]$} \\
\hline Liver cancer & silbinin, citrous flavonoids & {$[25]$} \\
\hline Lung cancer & vitamins A and E & {$[154-157]$} \\
\hline Ovary cancer & Vitamin A, D, antioxidants & {$[176-178]$} \\
\hline Pancreatic cancer & Vitamins and isoflavones & {$[182-184]$} \\
\hline Prostate cancer & lycopene, phytoesterogen & {$[133-153]$} \\
\hline
\end{tabular}

\section{Challenges, Hypes, Hopes and Futuristic Role of} Nutraceuticals

Most of the success of nutraceuticals is based on selfprescription and own individual experiences. Still it is far to realize the miraculous benefits of nutraceuticals unless controlled clinical trials support the evidences and facts of nutraceutical preventive therapeutic efficacy. Major challenge is early detection of premalignancy and timely effective oncological treatment. In spite of all tools available, cancer is major health hazard. The major available data on nutriceuticals in cancer comes from epidemiological health and population statistics. The reduced cancer incidence due to nutraceuticals seems a hype but greater hopes are anticipated with advancements in food science. However, still cancer remains a major threat because of high mortality compounded with incomplete success of chemotherapy, oncotherapy and surgery intervention. In future, bioengineered nutraceuticals will play significant role in cancer prevention as alternative oncotherapeutics.

\section{CONCLUSION}

Nutraceuticals still are growing in number and investigations suggest high hopes of nutraceuticals in cancer prevention. The role of governments and globalization will certainly support the health risks and clinical trials on nutraceuticals. The nutraceuticals are becoming popular as they are harmless and natural food constituents. The nutraceuticals are still food supplements and last 5 years demonstrated enormous change in the perception of nutraceuticals as cancer preventive and therapeutic supplements in cancers of different organs.

\section{ACKNOWLEGEMENTS}

The author acknowledges the opportunity of engineering and biotechnology internship under supervision of Dr. Zoreh Moshir and Dr. Ching J. Chen at FAMU-FSU College of Engineering, Tallahassee, Florida.

\section{REFERENCES}

[1] Baichwal RS. Developments in nutraceuticals. Pharm Times 1999; 1: $19-20$

[2] Dureja D, Kaushik D, Kumar V. Developments in nutraceuticals Indian J Pharmacol 2003; 35: 363-72.

[3] Malik A, Kumar P, Kaushik N, Singh A. The potential of nutraceuticals. Pharm Rev 2008; 6(2).

[4] Tripathi YB, Tripathi P, Arjmandi BH. Nutraceuticals and cancer management. Front Biosci 2005; 10: 1607-18.

[5] Rackley JD, Clark PE, Hall HC. Lycopene, Silbinin, Shark cartilage, Vitamin D, Vitamin D to decrease osteoporosis and bone pain, Green tea, Selenium and vitamin E, Grape seed extract, Modified citrus, pectin, Soy, PC-SPES are cited as prostate cancer protective food supplements. Urol Clin North Am 2006; 33(2): 237-46.

[6] Rishi RK. Nutraceuticals: Borderline between food and drug? Pharmacol Rev 2006; 1: 51-3.

[7] Spitberg VL. Bovine milk fat globule membrane as a potent nutraceutical. J Dairy Sci 2005; 88: 2289-94

[8] German JB, Dillard CJ. Phytochemicals: nutraceuticals and human health. J Sci Food Agric 2000; 80: 1744-56.

[9] Hennekens CH. Antioxidant vitamins and cancer. Am J Med 1994; 97(3A): 2S-4S

[10] Zhao Y, Li J, Wang J, Xing Y, Geng M. Role of cell surface oligosaccharides of mouse mammary tumor cell lines in cancer metastasis. Indian J Biochem Biophys 2007; 44(3): 145-51.

[11] Conkin KA. Dietary polyunsaturated fatty acids: impact on cancer chemotherapy and radiation - Review: essential fatty acids/cancer. Altern Med Rev 2009; 1: 1-21. Internet: http://findarticles.com/p/ articles/mi_m0FDN/is_1_7/ai_83582815

[12] Nair V. Soy and cancer survivors: dietary supplementation with fermented soy nutraceutical, Haelan951 in patients who survived terminal cancers. Townsend Letter for Doctors and Patients 2004. Internet: http://findarticles.com/p/articles/mi_m0ISW/is_256/ ai_n6258846?tag=rel.res4

[13] Jung KJ. Breast cancer inhibition by grape constituents. Ph.D dissertation submitted to University of Illinois at Urbana-Champaign 2005. Internet: http://americanwildfoods.com/ applications/DocumentLibraryManager/upload/pdf5.pdf

[14] Lambert JD, Lee MJ, Lu H, et al. Epigallocatechin-3-Gallate is absorbed but extensively glucuronidated following oral administration to mice. J Nutr 2003; 133: 4172-7.

[15] Sharma R, Kline RP, Wu EX, Katz JK. Rapid in vivo Taxotere quantitative chemosensitivity response by 4.23 Tesla sodium MRI and histoimmunostaining features in N-Methyl-N-Nitrosourea induced breast tumors in rats, Cancer Cell Int 2005; 5(26): 129-42.

[16] Sharma R, Katz JK. Taxotere chemosensitivity evaluation in mice prostate tumor: validation and diagnostic accuracy of quantitative measurement of tumor characteristics by MRI, PET, and histology of mice tumor. Technol Cancer Res Treat 2008; 3(7): 155-268.

[17] Stagnaro E, Tumino R, Parodi S, et al. Non-Hodgkin's Lymphoma and type of tobacco smoke. Cancer Epidemiol Biomarkers Prev 2004; 13: 431-7.

[18] Beliveau R, Gingras D. Green tea: prevention and treatment of cancer by nutraceuticals. Lancet 2004; 364: 1021-2.

[19] Béliveau R, Gingras D. Role of nutrition in preventing cancer. Can Fam Physician 2007; 53(11): 1905-11.

[20] Cooper R, Morré DJ, Morré DM. Medicinal benefits of green tea: part II. review of anticancer properties. J Altern Complement Med 2005; 11(4): 639-52.

[21] Wildman REC. Classifying nutraceuticals. In: Wildman REC, Ed. Nutraceutical and Functional Foods. CRC Press LLC, Boca Raten 2001; pp. 13-30.

[22] Grant WB. An ecologic study of dietary and solar UV-B links to breast cancer mortality rates. Cancer 2002; 94(1): 272-81.

[23] Over view of nutrition in cancer care. US national Institute of Health. NCI http://www.cancer.gov/cancerinfo/pdq/supportivecare/ nutrition

[24] Complementary and Alternative Medicine in Cancer Treatment: Questions and Answers. US national Institute of Health. NCI. http://www.cancer.gov/cancertopics/factsheet/therapy/CAM

[25] Fullerton FR, Greenman DL, Maccarty CC, Bucci TJ. Increased incidence of spontaneous and 2-acetylaminofluorene-induced liver and bladder tumors in B6C3F1 mice fed AIN-76. A diet versus NIH07 diet. Toxicol Sci 1991; 16: 51-60. 
[26] Barnes PM, Bloom B. Complementary and alternative medicine use among adults and children: United States, 2007. http://www. cdc.gov/nchs/data/nhsr/nhsr012.pdf

[27] Nutraceuticals and cancer management. Publication: Nutraceuticals International. Publication Date: 01-JUL-00. www.accessmylibrary. com/coms2/summary_0286-28013485_ITM - 22k

[28] Roudebush P, Davenport DJ, Novotny BJ. The use of nutraceuticals in cancer therapy. Vet Clin North Am Small Anim Pract 2004; 34(1): 249-69.

[29] Washington State University the Fred Hutchinson Cancer Research Center. http://findarticles.com/p/articles/mi_hb223/is_/ ai_n28934462-45k

[30] Watson RR. Functional Foods and Nutraceuticals in Cancer Prevention by Ronald Ross Watson (Hardcover - Jul 7, 2003) ISBN: 978-0-8138-1854-2 Hardcover 315 pages. July 2003, WileyBlackwell. Iowa State Press, Blackwell Publishing, Ames, Iowa. Source: Cancer: Nutrition and Health Issues : NIH. National Cancer Institute. www.nutrition.gov/nal_display/index.php?info_ center $=11 \&$ tax_level $=2 \&$ tax

[31] Overcash JA. Vitamin D in older patients with cancer. Clin J Oncol Nurs 2008; 12(4): 655-62.

[32] Zhang SM, Cook NR, Albert CM, Gaziano JM, Buring JE, Manson JE. Effect of combined folic acid, vitamin B6, and vitamin B12 on cancer risk in women: a randomized trial. JAMA 2008; 300(17): 2012-21

[33] Milner JA. Nutrition and cancer: essential elements for a roadmap. Cancer Lett 2008; 269(2): 189-98

[34] Holick MF. Vitamin D and sunlight: strategies for cancer prevention and other health benefits. Clin J Am Soc Nephrol 2008; 3(5): 1548-54.

[35] Giovannucci E. Vitamin D status and cancer incidence and mortality. Adv Exp Med Biol. 2008; 624: 31-42.

[36] Beres S. Vitamin D: cancer prevention's sunny future? J Natl Cancer Inst 2008; 100(5): 292-7.

[37] Dizdar O, Harputluoglu H, Altundag K. Vitamin D intake and breast cancer risk in postmenopausal women. Arch Intern Med 2007; 167(22): 2532.

[38] Sood MM, Sood AR. Dietary vitamin D and decreases in cancer rates: Canada as the national experiment. Am J Clin Nutr 2007; 86(5): 1549.

[39] Slatore CG, Littman AJ, Au DH, Satia JA, White E. Long-term use of supplemental multivitamins, vitamin $\mathrm{C}$, vitamin $\mathrm{E}$, and folate does not reduce the risk of lung cancer. Am J Respir Crit Care Med 2008; 177(5): 524-30.

[40] Peters U, Littman AJ, Kristal AR, Patterson RE, Potter JD, White E. Vitamin E and selenium supplementation and risk of prostate cancer in the Vitamins and lifestyle (VITAL) study cohort. Cancer Causes Control 2008; 19(1): 75-87.

[41] Larsson SC, Bergkvist L, Näslund I, Rutegård J, Wolk A. Vitamin A, retinol, and carotenoids and the risk of gastric cancer: a prospective cohort study. Am J Clin Nutr 2007; 85(2): 497-503.

[42] Greenwald P, Anderson D, Nelson SA, Taylor PR. Clinical trials of vitamin and mineral supplements for cancer prevention. Am J Clin Nutr 2007; 85(1): 314S-317S

[43] Fairfield K, Stampfer M. Vitamin and mineral supplements for cancer prevention: issues and evidence. Am J Clin Nutr 2007; 85(1): 289S-292S

[44] Schwartz GG, Blot WJ. Vitamin D status and cancer incidence and mortality: something new under the sun. J Natl Cancer Inst 2006; 98(7): 428-30.

[45] Lee IM, Gaziano JM, Buring JE. Vitamin E in the prevention of prostate cancer: where are we today? J Natl Cancer Inst 2006; 98(4): 225-7.

[46] Zhang SM, Moore SC, Lin J, et al. Folate, vitamin B6, multivitamin supplements, and colorectal cancer risk in women. Am J Epidemiol 2006; 163(2): 108-15.

[47] Punnam SR. Role of vitamin E in the prevention of cardiovascular disease and cancer. JAMA 2005 ; 294(19): 2432

[48] Lin J, Cook NR, Lee IM, Manson JE, Buring JE, Zhang SM. Total magnesium intake and colorectal cancer incidence in women. Cancer Epidemiol Biomarkers Prev 2006; 15(10): 2006-9.

[49] Kushi LH, Byers T, Doyle C, et al. American Cancer Society 2006 Nutrition and Physical Activity Guidelines Advisory Committee. American Cancer Society Guidelines on Nutrition and Physical Activity for cancer prevention: reducing the risk of cancer with healthy food choices and physical activity. CA Cancer J Clin 2006; 56(5): 254.

[50] Huang HY, Caballero B, Chang S, et al. The efficacy and safety of multivitamin and mineral supplement use to prevent cancer and chronic disease in adults: a systematic review for a National Institutes of Health state-of-the-science conference. Ann Intern Med 2006; 145(5): 372-85.

[51] Hayes DP. The protective role of fruits and vegetables against radiation-induced cancer. Nutr Rev 2005; 63(9): 303-11.

[52] Johnson IT. Micronutrients and cancer. Proc Nutr Soc 2004; 63(4): 587-95.

[53] Gromadzińska J, Reszka E, Bruzelius K, Wasowicz W, Akesson B. Selenium and cancer: biomarkers of selenium status and molecular action of selenium supplements. Eur J Nutr 2008; 47 (Suppl 2): 29 50

[54] Reid ME, Duffield-Lillico AJ, Slate E, et al. The nutritional prevention of cancer: $400 \mathrm{mcg}$ per day selenium treatment. Nutr Cancer 2008; 60(2): 155-63.

[55] Marshall JR, Sakr W, Wood D, et al. Design and progress of a trial of selenium to prevent prostate cancer among men with high-grade prostatic intraepithelial neoplasia. Cancer Epidemiol Biomarkers Prev 2006 ; 15(8): 1479-84.

[56] Drake EN. Cancer chemoprevention: selenium as a prooxidant, not an antioxidant. Med Hypotheses 2006; 67(2): 318-22.

[57] Duffield-Lillico AJ, Shureiqi I, Lippman SM. Can selenium prevent colorectal cancer? A signpost from epidemiology. J Natl Cancer Inst 2004; 96(22): 1645-7.

[58] Park Y, Leitzmann MF, Subar AF, Hollenbeck A, Schatzkin A. Dairy food, calcium, and risk of cancer in the NIH-AARP Diet and Health Study. Arch Intern Med 2009; 169(4): 391-401.

[59] Evans J. Antioxidant supplements to prevent or slow down the progression of AMD: a systematic review and meta-analysis. Eye 2008; 22(6): 751-60.

[60] Bardia A, Tleyjeh IM, Cerhan JR, et al. Efficacy of antioxidant supplementation in reducing primary cancer incidence and mortality: systematic review and meta-analysis. Mayo Clin Proc 2008; 83(1): 23-34

[61] Khan N, Afaq F, Mukhtar H. Cancer chemoprevention through dietary antioxidants: progress and promise. Antioxid Redox Signal 2008; 10(3): 475-510.

[62] Hercberg S, Czernichow S, Galan P. Antioxidant vitamins and minerals in prevention of cancers: lessons from the SU.VI.MAX study. Br J Nutr 2006; 96 (Suppl 1): S28-30.

[63] Bjelakovic G, Nagorni A, Nikolova D, Simonetti RG, Bjelakovic M, Gluud C. Meta-analysis: antioxidant supplements for primary and secondary prevention of colorectal adenoma. Aliment Pharmacol Ther 2006; 24(2): 281-91.

[64] Borek C. Dietary antioxidants and human cancer. Integr Cancer Ther 2004; 3(4): 333-41.

[65] Bjelakovic G, Nikolova D, Simonetti RG, Gluud C. Antioxidant supplements for prevention of gastrointestinal cancers: a systematic review and meta-analysis. Lancet 2004; 364(9441): 1219-28.

[66] Bairati I, Meyer F, Gélinas M, et al. Randomized trial of antioxidant vitamins to prevent second primary cancers in head and neck cancer patients. J Natl Cancer Inst 2005; 97(7): 481-8.

[67] Chen YQ, Berquin IM, Daniel LW, et al. Omega-3 fatty acids and cancer risk. JAMA 2006; 296(3): 282

[68] Colomer R, Moreno-Nogueira JM, García-Luna PP, et al. N-3 fatty acids, cancer and cachexia: a systematic review of the literature. $\mathrm{Br}$ J Nutr 2007; 97(5): 823-31.

[69] Granados S, Quiles JL, Gil A, Ramírez-Tortosa MC. Dietary lipids and cancer. Nutr Hosp 2006; 21(2): 42-52, 44-54.

[70] Walle T, Wen X, Walle UK. Improving metabolic stability of cancer chemoprotective polyphenols. Expert Opin Drug Metab Toxicol 2007; 3(3): 379-88.

[71] Thomasset SC, Berry DP, Garcea G, Marczylo T, Steward WP, Gescher AJ. Dietary polyphenolic phytochemicals--promising cancer chemopreventive agents in humans? A review of their clinical properties. Int J Cancer 2007; 120(3): 451-8.

[72] Nagle DG, Ferreira D, Zhou YD. Epigallocatechin-3-gallate (EGCG): chemical and biomedical perspectives. Phytochemistry 2006; 67(17): 1849-55

[73] Russo GL. Ins and outs of dietary phytochemicals in cancer chemoprevention. Biochem Pharmacol 2007; 74(4): 533-44.

[74] Rannikko A, Petas A, Rannikko S, Adlercreutz H. Plasma and prostate phytoestrogen concentrations in prostate cancer patients 
after oral phytoestogen supplementation. Prostate 2006; 66(1): 827.

[75] Ganry O. Phytoestrogens and prostate cancer risk. Prev Med 2005; 41(1): 1-6.

[76] Holzbeierlein JM, McIntosh J, Thrasher JB. The role of soy phytoestrogens in prostate cancer. Curr Opin Urol 2005; 15(1): 17-22.

[77] Lee KW, Lee HJ, Lee CY. Vitamins, phytochemicals, diets, and their implementation in cancer chemoprevention. Crit Rev Food Sci Nutr 2004; 44(6): 437-52.

[78] Messina MJ, Wood CE. Soy isoflavones, estrogen therapy, and breast cancer risk: analysis and commentary. Nutr J 2008; 7: 17.

[79] Miller MF, Bellizzi KM, Sufian M, Ambs AH, Goldstein MS, Ballard-Barbash R. Dietary supplement use in individuals living with cancer and other chronic conditions: a population-based study. J Am Diet Assoc 2008; 108(3): 483-94.

[80] Chlebowski RT, Johnson KC, Kooperberg C, et al. Women's Health Initiative Investigators. J Natl Cancer Inst 2008; 100(22): 1581-9.

[81] Lawson KA, Wright ME, Subar A, et al. Multivitamin use and risk of prostate cancer in the National Institutes of Health-AARP Diet and Health Study. J Natl Cancer Inst 2007; 99(10): 754-64.

[82] Hu J, Mery L, Desmeules M, Macleod M. Canadian Cancer Registries Epidemiology Research Group. Diet and vitamin or mineral supplementation and risk of rectal cancer in Canada. Acta Oncol 2007; 46(3): 342-54

[83] NIH State-of-the-Science Conference Statement on Multivitamin/Mineral Supplements and Chronic Disease Prevention. NIH Consens State Sci Statements 2006; 23(2): 1-30.

[84] Wright ME, Virtamo J, Hartman AM, et al. Effects of alphatocopherol and beta-carotene supplementation on upper aerodigestive tract cancers in a large, randomized controlled trial. Cancer 2007; 109(5): 891-8.

[85] Zhang SM, Cook NR, Albert CM, Gaziano JM, Buring JE, Manson JE. Effect of combined folic acid, vitamin B6, and vitamin B12 on cancer risk in women: a randomized trial. JAMA 2008; 300(17): 2012-2.

[86] Walsh PC. Effects of long-term vitamin E supplementation on cardiovascular events and cancer: a randomized controlled trial. J Urol 2005; 174(5): 1823-4.

[87] Pham DQ, Plakogiannis R. Vitamin E supplementation in cardiovascular disease and cancer prevention: Part 1. Ann Pharmacother 2005; 39(11): 1870-8.

[88] Ambrosini GL, De Klerk NH, Fritschi L, Mackerras D, Musk B. Fruit, vegetable, vitamin A intakes, and prostate cancer risk. Prostate Cancer Prostatic Dis 2008; 11(1): 61-6.

[89] Lewis SJ, Harbord RM, Harris R, Smith GD. Meta-analyses of observational and genetic association studies of folate intakes or levels and breast cancer risk. J Natl Cancer Inst 2006; 98(22): 1607-22.

[90] Van Patten CL, De Boer JG, Tomlinson Guns ES. Diet and dietary supplement intervention trials for the prevention of prostate cancer recurrence: a review of the randomized controlled trial evidence. $\mathbf{J}$ Urol 2008; 180(6): 2314-2.

[91] Curtis Nickel J, Shoskes D, Roehrborn CG, Moyad M. Nutraceuticals in prostate disease: The Urologist's Role. Rev Urol 2008; 10(3): 192-206.

[92] Demark-Wahnefried W. Dietary interventions in prostate cancer. Curr Urol Rep 2008; 9(3): 217-25.

[93] Bunker CH, McDonald AC, Evans RW, De la Rosa N, Boumosleh JM, Patrick AL. A randomized trial of lycopene supplementation in Tobago men with high prostate cancer risk. Nutr Cancer 2007; 57(2): 130-7.

[94] Pan SY, Ugnat AM, Mao Y, Wen SW, Johnson KC. Canadian Cancer Registries Epidemiology Research Group.A case-control study of diet and the risk of ovarian cancer. Cancer Epidemiol Biomarkers Prev 2004; 13(9): 1521-7.

[95] Sartippour MR, Rao JY, Apple S, et al. A pilot clinical study of short-term isoflavone supplements in breast cancer patients. Nutr Cancer 2004; 49(1): 59-65.

[96] Cho E, Hunter DJ, Spiegelman D, et al. Intakes of vitamins A, C and $\mathrm{E}$ and folate and multivitamins and lung cancer: a pooled analysis of 8 prospective studies. Int J Cancer 2006; 118(4): 970-8.

[97] Taylor PR, Greenwald P. Nutritional interventions in cancer prevention. J Clin Oncol 2005; 23(2): 333-45.
[98] Baron JA, Beach M, Wallace K, et al. Risk of prostate cancer in a randomized clinical trial of calcium supplementation. Cancer Epidemiol Biomarkers Prev 2005; 14(3): 586-9.

[99] Gallicchio L, Boyd K, Matanoski G, et al. Carotenoids and the risk of developing lung cancer: a systematic review. Am J Clin Nutr 2008; 88(2): 372-83.

[100] Hernáandez J, Syed S, Weiss G, et al. The modulation of prostate cancer risk with alpha-tocopherol: a pilot randomized, controlled clinical trial. J Urol 2005; 174(2): 519-22.

[101] Itsiopoulos C, Hodge A, Kaimakamis M. Can the Mediterranean diet prevent prostate cancer? Mol Nutr Food Res 2009; 53(2): 22739.

[102] Martinez-Gonzalez MA, Estruch R. Mediterranean diet, antioxidants and cancer: the need for randomized trials. Eur J Cancer Prev 2004; 13(4): 327-35.

[103] Ortega RM. Importance of functional foods in the Mediterranean diet. Public Health Nutr 2006; 9(8A): 1136-40.

[104] Itsiopoulos C, Hodge A, Kaimakamis M. Can the Mediterranean diet prevent prostate cancer? Mol Nutr Food Res 2009; 53: 227-39.

[105] Sandur SK, Pandey MK, Sung B, et al. Curcumin, demethoxycurcumin, bisdemethoxycurcumin, tetrahydrocurcumin and turmerones differentially regulate anti-inflammatory and anti-proliferative responses through a ROS-independent mechanism. Carcinogenesis 2007; 28(8): 1765-73.

[106] Walfisch S, Walfisch Y, Kirilov E, et al. Tomato lycopene extract supplementation decreases insulin-like growth factor-I levels in colon cancer patients. Eur J Cancer Prev 2007; 16(4): 298-303.

[107] Mathers JC, Coxhead JM, Tyson J. Nutrition and DNA repair-potential molecular mechanisms of action. Curr Cancer Drug Targets 2007; 7(5): 425-3.

[108] Tam CW, Mo CW, Yao KM, Shiu SY. Signaling mechanisms of melatonin in antiproliferation of hormone-refractory $22 \mathrm{Rv} 1$ human prostate cancer cells: implications for prostate cancer chemoprevention. J Pineal Res 2007; 42(2): 191-202.

[109] Katiyar SK. Matrix metalloproteinases in cancer metastasis: molecular targets for prostate cancer prevention by green tea polyphenols and grape seed proanthocyanidins. Endocr Metab Immune Disord Drug Targets 2006 ; 6(1): 17-24.

[110] Cross HS, Kállay E. Nutritional regulation of extrarenal vitamin D hydroxylase expression - potential application in tumor prevention and therapy. Future Oncol 2005; 1(3): 415-24.

[111] Dijsselbloem N, Vanden Berghe W, De Naeyer A, Haegeman G. Soy isoflavone phyto-pharmaceuticals in interleukin-6 affections. Multi-purpose nutraceuticals at the crossroad of hormone replacement, anti-cancer and anti-inflammatory therapy. Biochem Pharmacol 2004; 68(6): 1171-85.

[112] Nakamura K, Kariyazono H, Komokata T, Hamada N, Sakata R, Yamada K. Influence of preoperative administration of omega-3 fatty acid-enriched supplement on inflammatory and immune responses in patients undergoing major surgery for cancer. Nutrition 2005; 21(6): 639-49.

[113] Branda RF, Naud SJ, Brooks EM, Chen Z, Muss H. Effect of vitamin B12, folate, and dietary supplements on breast carcinoma chemotherapy--induced mucositis and neutropenia. Cancer 2004; 101(5): 1058-64

[114] Mooney LA, Madsen AM, Tang D, et al. Antioxidant vitamin supplementation reduces benzo(a)pyrene-DNA adducts and potential cancer risk in female smokers. Cancer Epidemiol Biomarkers Prev 2005; 14(1): 237-42.

[115] Mathers JC. Reversal of DNA hypomethylation by folic acid supplements: possible role in colorectal cancer prevention. Gut 2005; 54(5): 579-81.

[116] Chen J, Gammon MD, Chan W, et al. One-carbon metabolism, MTHFR polymorphisms, and risk of breast cancer. Cancer Res 2005; 65(4): 1606-14.

[117] DiSilvestro RA, Goodman J, Dy E, Lavalle G. Soy isoflavone supplementation elevates erythrocyte superoxide dismutase, but not plasma ceruloplasmin in postmenopausal breast cancer survivors. Breast Cancer Res Treat 2005; 89(3): 251-5.

[118] Liu RH. Potential synergy of phytochemicals in cancer prevention: mechanism of action. J Nutr 2004; 134(12): 3479S-3485S.

[119] McGarr SE, Ridlon JM, Hylemon PB. Diet, anaerobic bacterial metabolism, and colon cancer: a review of the literature. J Clin Gastroenterol 2005; 39(2): 98-109.

[120] Mandel S, Packer L, Youdim MB, Weinreb O. Proceedings from the Third International Conference on Mechanism of Action 
of Nutraceuticals. J Nutr Biochem 2005; 16(9): 513-20. http:// oxyclubcalifornia.org/content/ICMAN4.pdf

[121] Sharma R. Rapid in vivo Taxotere quantitative chemosensitivity response by 4.23 Tesla sodium MRI and histo-immunostaining features in N-Methyl-N-Nitrosourea induced breast tumors in rats. Cancer Cell Int 2005; 5: 26.

[122] Messina M, McCaskill-Stevens W, Lampe JW. Addressing the soy and breast cancer relationship: review, commentary, and workshop proceedings. J Natl Cancer Inst 2006; 98(18): 1275-84.

[123] Maskarinec G. Soy foods for breast cancer survivors and women at high risk for breast cancer? J Am Diet Assoc 2005; 105(10): 15248.

[124] Vantyghem SA, Wilson SM, Postenka CO, Al-Katib W, Tuck AB, Chambers AF. Dietary genistein reduces metastasis in a postsurgical orthotopic breast cancer model. Cancer Res 2005; 65(8): 3396403.

[125] Speers C, Brown P. Breast cancer prevention using calcium and vitamin D: a bright future? J Natl Cancer Inst 2008; 100(22): 15624.

[126] Tomar RS, Shiao R. Early life and adult exposure to isoflavones and breast cancer risk. J Environ Sci Health C Environ Carcinog Ecotoxicol Rev 2008; 26(2): 113-73.

[127] Powles TJ, Howell A, Evans DG, et al. Red clover isoflavones are safe and well tolerated in women with a family history of breast cancer. Menopause Int 2008; 14(1): 6-12.

[128] Ishitani K, Lin J, Manson JE, Buring JE, Zhang SM. A prospective study of multivitamin supplement use and risk of breast cancer. Am J Epidemiol 2008; 167(10): 1197-206.

[129] Dorjgochoo T, Shrubsole MJ, Shu XO, et al. Vitamin supplement use and risk for breast cancer: the Shanghai Breast Cancer Study. Breast Cancer Res Treat 2008; 111(2): 269-78.

[130] Velentzis LS, Woodside JV, Cantwell MM, Leathem AJ, Keshtgar MR. Do phytoestrogens reduce the risk of breast cancer and breast cancer recurrence? What clinicians need to know. Eur J Cancer 2008; 44(13): 1799-806.

[131] Ericson U, Sonestedt E, Gullberg B, Olsson H, Wirfält E. High folate intake is associated with lower breast cancer incidence in postmenopausal women in the Malmö Diet and Cancer cohort. Am J Clin Nutr 2007; 86(2): 434-43.

[132] Lajous M, Lazcano-Ponce E, Hernandez-Avila M, Willett W, Romieu I. Folate, vitamin B(6), and vitamin B(12) intake and the risk of breast cancer among Mexican women. Cancer Epidemiol Biomarkers Prev 2006; 15(3): 443-8.

[133] Meyer F, Galan P, Douville P, et al. Antioxidant vitamin and mineral supplementation and prostate cancer prevention in the SU.VI.MAX trial. Int J Cancer 2005; 20;116(2):182-6.

[134] Kranse R, Dagnelie PC, Van Kemenade MC, et al. Dietary intervention in prostate cancer patients: PSA response in a randomized double-blind placebo-controlled study. Int J Cancer 2005; 113(5): 835-40.

[135] Demark-Wahnefried W. Dietary interventions in prostate cancer. Curr Urol Rep 2008; 9(3): 217-25.

[136] Guy L, Védrine N, Urpi-Sarda M, et al. Orally administered isoflavones are present as glucuronides in the human prostate. Nutr Cancer 2008; 60(4): 461-8.

[137] Grainger EM, Schwartz SJ, Wang S, et al. A combination of tomato and soy products for men with recurring prostate cancer and rising prostate specific antigen. Nutr Cancer 2008; 60(2): 145-54.

[138] Syed DN, Suh Y, Afaq F, Mukhtar H. Dietary agents for chemoprevention of prostate cancer. Cancer Lett 2008; 265(2): 167-76.

[139] Grainger EM, Kim HS, Monk JP, et al. Consumption of dietary supplements and over-the-counter and prescription medications in men participating in the Prostate Cancer Prevention Trial at an academic center. Urol Oncol 2008; 26(2): 125-32.

[140] Kristal AR, Arnold KB, Schenk JM, et al. Dietary patterns, supplement use, and the risk of symptomatic benign prostatic hyperplasia: results from the prostate cancer prevention trial. Am J Epidemiol 2008; 167(8): 925-34.

[141] Syed DN, Khan N, Afaq F, Mukhtar H. Chemoprevention of prostate cancer through dietary agents: progress and promise. Cancer Epidemiol Biomarkers Prev 2007; 16(11): 2193-203.

[142] Molokwu CN. Calcium supplements in patients with prostate cancer. BJU Int 2007; 100(6): 1411.
[143] Weinstein SJ, Stolzenberg-Solomon R, Pietinen P, Taylor PR, Virtamo J, Albanes D. Dietary factors of one-carbon metabolism and prostate cancer risk. Am J Clin Nutr 2006; 84(4): 929-35.

[144] Brawley OW. The potential for prostate cancer chemoprevention. Rev Urol 2002; 4 (Suppl 5): S11-7.

[145] Moyad MA, Sakr WA, Hirano D, Miller GJ. Complementary medicine for prostate cancer: effects of soy and fat consumption. Rev Urol 2001; 3(2): S20-30.

[146] Bemis DL, Capodice JL, Costello JE, Vorys GC, Katz AE, Buttyan $\mathrm{R}$. The use of herbal and over-the-counter dietary supplements for the prevention of prostate cancer. Curr Oncol Rep 2006; 8(3): 22836.

[147] Santillo VM, Lowe FC. Role of vitamins, minerals and supplements in the prevention and management of prostate cancer. Int Braz J Urol 2006; 32(1): 3-14.

[148] Dhillon N, Aggarwal BB, Newman RA, et al. Phase II trial of curcumin in patients with advanced pancreatic cancer. Clin Cancer Res 2008; 14(14): 4491-9.

[149] Chang ET, Hedelin M, Adami HO, Grönberg H, Bälter KA. Re: Zinc supplement use and risk of prostate cancer. J Natl Cancer Inst 2004; 96(14): 1108-9.

[150] Shukla S, Gupta S. Dietary agents in the chemoprevention of prostate cancer. Nutr Cancer 2005; 53(1): 18-32.

[151] Sonn GA, Aronson W, Litwin MS. Impact of diet on prostate cancer: a review. Prostate Cancer Prostatic Dis 2005; 8(4): 304-10.

[152] Weinstein SJ, Wright ME, Lawson KA, et al. Serum and dietary vitamin $\mathrm{E}$ in relation to prostate cancer risk. Cancer Epidemiol Biomarkers Prev 2007; 16(6): 1253-9.

[153] Wright ME, Weinstein SJ, Lawson KA, et al. Supplemental and dietary vitamin $\mathrm{E}$ intakes and risk of prostate cancer in a large prospective study. Cancer Epidemiol Biomarkers Prev 2007; 16(6): 1128-35.

[154] Byers T. Nutrition and lung cancer: lessons from the differing effects of foods and supplements. Am J Respir Crit Care Med 2008; 177(5): 470-1.

[155] Gallicchio L, Boyd K, Matanoski G, et al. Carotenoids and the risk of developing lung cancer: a systematic review. Am J Clin Nutr 2008; 88(2): 372-83

[156] Mahabir S, Schendel K, Dong YQ, Barrera SL, Spitz MR, Forman MR. Dietary alpha-, beta-, gamma- and delta-tocopherols in lung cancer risk. Int J Cancer 2008; 123(5): 1173-80.

[157] Meyer F, Bairati I, Jobin E, et al. Acute adverse effects of radiation therapy and local recurrence in relation to dietary and plasma beta carotene and alpha tocopherol in head and neck cancer patients. Nutr Cancer 2007; 59(1): 29-35.

[158] Franco A, Sikalidis AK, Solís Herruzo JA. Colorectal cancer: influence of diet and lifestyle factors. Rev Esp Enferm Dig 2005 97(6): 432-48.

[159] Hubner RA, Houlston RS. Late and colorectal cancer prevention. Br J Cancer 2009; 100(2): 233-9.

[160] Sanderson P, Stone E, Kim YI, et al. Folate and colo-rectal cancer risk. Br J Nutr 2007; 98(6): 1299-304.

[161] Kim YI. Folate and colorectal cancer: an evidence-based critical review. Mol Nutr Food Res 2007; 51(3): 267-92.

[162] Bingham S. The fibre-folate debate in colo-rectal cancer. Proc Nutr Soc 2006; 65(1): 19-23.

[163] Jaszewski R, Misra S, Tobi M, et al. Folic acid supplementation inhibits recurrence of colorectal adenomas: a randomized chemoprevention trial. World J Gastroenterol 2008; 14(28): 4492 8.

[164] Weingarten MA, Zalmanovici A, Yaphe J. Dietary calcium supplementation for preventing colorectal cancer and adenomatous polyps. Cochrane Database Syst Rev 2008; 1: CD003548.

[165] Benamouzig R, Chaussade S. Calcium supplementation for preventing colorectal cancer: where do we stand? Lancet 2004; 364(9441): 1197-9.

[166] Kripke C. Calcium and prevention of colorectal cancer. Am Fam Physician 2004; 70(11): 2109.

[167] Flood A, Peters U, Chatterjee N, Lacey JV Jr, Schairer C, Schatzkin A. Calcium from diet and supplements is associated with reduced risk of colorectal cancer in a prospective cohort of women. Cancer Epidemiol Biomarkers Prev 2005; 14(1): 126-32.

[168] Ryan-Harshman M, Aldoori W. Diet and colorectal cancer: Review of the evidence. Can Fam Physician 2007; 53(11): 1913-20.

[169] Vrieling A, Voskuil DW, Bonfrer JM, et al. Lycopene supplementation elevates circulating insulin-like growth factor binding 
protein-1 and -2 concentrations in persons at greater risk of colorectal cancer. Am J Clin Nutr 2007; 86(5): 1456-62.

[170] Das D, Arber N, Jankowski JA. Chemoprevention of colorectal cancer. Digestion 2007; 76(1): 51-67.

[171] Ishikawa H, Akedo I, Otani T, et al. Randomized trial of dietary fiber and Lactobacillus casei administration for prevention of colorectal tumors. Int J Cancer 2005; 116(5): 762-7.

[172] Harris DM, Go VL. Vitamin D and colon carcinogenesis. J Nutr 2004; 134(12): 3463S-71S.

[173] Dong LM, Kristal AR, Peters U, et al. Dietary supplement use and risk of neoplastic progression in esophageal adenocarcinoma: a prospective study. Nutr Cancer 2008; 60(1): 39-48.

[174] Bjelakovic G, Nikolova D, Simonetti RG, Gluud C. Antioxidant supplements for preventing gastrointestinal cancers. Cochrane Database Syst Rev 2008; 3: CD004183.

[175] Fock KM, Talley N, Moayyedi P, et al. Asia-Pacific Gastric Cancer Consensus Conference. Asia-Pacific consensus guidelines on gastric cancer prevention. J Gastroenterol Hepatol 2008; 23(3): 351-65.

[176] McCullough ML, Bandera EV, Moore DF, Kushi LH. Vitamin D and calcium intake in relation to risk of endometrial cancer: a systematic review of the literature. Prev Med 2008; 46(4): 298-302.
[177] Schumann SA, Ewigman B. Double-dose vitamin D lowers cancer risk in women over 55. J Fam Pract 2007; 56(11): 907-10.

[178] Tung KH, Wilkens LR, Wu AH, et al. Association of dietary vitamin A, carotenoids, and other antioxidants with the risk of ovarian cancer. Cancer Epidemiol Biomarkers Prev 2005; 14(3): 669-76.

[179] Russell NC, Hoelscher DM, Lowenstein N. Patients previously treated for lymphoma consume inadequate or excessive amounts of five key nutrients. J Soc Integr Oncol 2007; 5(3): 118-24.

[180] Hercberg S, Ezzedine K, Guinot C, et al. Antioxidant supplementation increases the risk of skin cancers in women but not in men. $J$ Nutr 2007; 137(9): 2098-105.

[181] Larsson SC, Håkansson N, Giovannucci E, Wolk A. Folate intake and pancreatic cancer incidence: a prospective study of Swedish women and men. J Natl Cancer Inst 2006; 98(6): 407-13.

[182] Larsson SC, Giovannucci E, Wolk A. Methionine and vitamin B6 intake and risk of pancreatic cancer: a prospective study of Swedish women and men. Gastroenterology 2007; 132(1): 113-8.

[183] Vitamin D may cut risk of pancreatic cancer. Mayo Clin Health Lett 2007; 25(1): 4.

[184] Sandler RS, Halabi S, Kaplan EB, Baron JA, Paskett E, Petrelli NJ. Use of vitamins, minerals, and nutritional supplements by participants in a chemoprevention trial. Cancer 2008; 91(5): 1040-5.

(C) Rakesh Sharma; Licensee Bentham Open.

This is an open access article licensed under the terms of the Creative Commons Attribution Non-Commercial License (http://creativecommons.org/licenses/by$\mathrm{nc} / 3.0 /$ ) which permits unrestricted, non-commercial use, distribution and reproduction in any medium, provided the work is properly cited. 